\title{
Cultural and Technological Retrospectives of the Coliva in the Republic of Moldova
}

By Rodica Siminiuc, Dinu Țurcanu, Daniela Pojar, Rodica Cujba, Viorica Cazac, Olga Gutium \& Carolina Grosu

Technical University of Moldova

Abstract- Food traditions were created and shaped by the contacts between cultures that met, overlapped and mixed in a history made up of habits, knowledge, specificities, shared experiences that build the personal and collective identity of each people and from which it nourishes the feeling of "pride of belonging". Thus, traditional foods play an important role in local identity, consumer behavior, the transfer of cultural heritage for future generations and the interaction of this heritage with the rest of the world. Coliva is a traditional dish based on boiled wheat that is used liturgically in the Eastern Orthodox Church for commemorations of the dead.

The purpose of this paper is to capitalize on and promote the coliva as a traditional culinary product of the Republic of Moldova and as a tool for communicating the identity values of a people. Over time, the coliva has become the expression of culture, the object and subject of cultural change, a condensate of social, environmental, historical and religious values.

Keywords: coliva, food traditions, culture, gastronomy, technological aspects, religion.

GJHSS-C Classification: FOR Code: 200299

Strictly as per the compliance and regulations of:

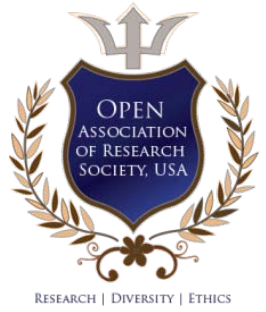

(C) 2020. Rodica Siminiuc, Dinu Țurcanu, Daniela Pojar, Rodica Cujba, Viorica Cazac, Olga Gutium \& Carolina Grosu. This is a research/review paper, distributed under the terms of the Creative Commons Attribution-Noncommercial 3.0 Unported License http://creativecommons.org/licenses/by-nc/3.0/), permitting all non-commercial use, distribution, and reproduction in any medium, provided the original work is properly cited. 


\title{
Cultural and Technological Retrospectives of the Coliva in the Republic of Moldova
}

\author{
Rodica Siminiuc $^{\alpha}$, Dinu Țurcanu ${ }^{\sigma}$, Daniela Pojar ${ }^{\circ}$, Rodica Cujba ${ }^{\omega}$, Viorica Cazac ${ }^{*}$, Olga Gutium ${ }^{\S}$ \\ \& Carolina Grosu ${ }^{x}$
}

Abstract- Food traditions were created and shaped by the contacts between cultures that met, overlapped and mixed in a history made up of habits, knowledge, specificities, shared experiences that build the personal and collective identity of each people and from which it nourishes the feeling of "pride of belonging". Thus, traditional foods play an important role in local identity, consumer behavior, the transfer of cultural heritage for future generations and the interaction of this heritage with the rest of the world. Coliva is a traditional dish based on boiled wheat that is used liturgically in the Eastern Orthodox Church for commemorations of the dead.

The purpose of this paper is to capitalize on and promote the coliva as a traditional culinary product of the Republic of Moldova and as a tool for communicating the identity values of a people. Over time, the coliva has become the expression of culture, the object and subject of cultural change, a condensate of social, environmental, historical and religious values. He is a formidable driver of well-being and health. Over time, the coliva has symbolically served several areas and meanings of culture, magically providing for the spiritual and material needs of the Moldovan people.

Keywords: coliva, food traditions, culture, gastronomy, technological aspects, religion.

\section{INTRODUCTION}

T he archetypal binomial, of great charm and meaning, condensing in itself two spheres of existence, which sanction man's belonging to the kingdom of nature on the one hand and, by virtue of his reasoning capacity, to that of culture on the other, is indispensable. The kitchen always keeps nature and culture close. If food is synonymous with subsistence and continuity, a practice necessary for the continuation of life, culture is the result of intellectual and imaginary

Author $\alpha$ : Food and Nutrition Department, Technical University of Moldova, Chisinau, Republic of Moldova.

e-mail: rodica.siminiuc@adm.utm.md

Author $\sigma:$ Informatization, Partnerships, Institutional Image and Communication Office, Technical University of Moldova, Chisinau, Republic of Moldova.

Author $\rho$ : Department of Management, Economics and Finance, Technical University of Moldova, Chisinau, Republic of Moldova.

Author w: Direction of Scientific Investigations, Technical University of Moldova, Chisinau, Republic of Moldova.

Author $¥$ : Design and Polygraph Technologies, Technical University of Moldova, Chisinau, Republic of Moldova.

Author \$: Food and Nutrition Department, Technical University of Moldova, Chisinau, Republic of Moldova.

Author $\chi$ : Food and Nutrition Department, Technical University of Moldova, Chisinau, Republic of Moldova. activity that places man above other species in the animal kingdom.

Each food culture has its own identity that communicates its origins, transformation processes, economic role played in the past and present and the social composition of the population, the result of conditions, processes, functions, cultural meanings, symbolic values and attributions of values. Therefore, it is obvious the centrality that food, as a crossroads of different cultural realities, assumes in each civilization, not only as a material value, but also for the magnitude of determinations and correlations, as well as for the symbolism it assumes, "Subject" with which the community characterizes the territory and has its roots in it.

It is easy to demonstrate the connection between the different ways of feeding people and the natural environment in which they live and have lived over the centuries. It is just as easy to point out the presence of food from cultural exchanges in their kitchen. In fact, nutrition by reaffirming the unitary status of the human condition, affirms its sacredness by ritualizing its practices. Food philosophy proposes the reading of each dish as a mixture of the history, culture and traditions of a territory and its people (Grimaldi, 2012), (Fieldhouse, 1998).

Food, in its many aspects, is central to national culture, conveying our identity as our mother tongue does. It contains the story of a country, a reference firmly rooted in its lexical and dialectal roots. Through its way of eating, the human being transmits messages, creates identity, establishes such differences, that gastronomy can certainly be considered what distinguishes different civilizations.

Food traditions, like all traditions, related to material culture that maintain a dense network of relationships between them, were in fact created and shaped by the contacts between cultures that met, overlapped and intermingled a history made up of habits, knowledge, specificities, shared experiences that build the personal and collective identity of each people and from which the feeling of "pride of belonging" is nourished. The messages transmitted by a food culture can be of different natures, but, in any case, they always communicate identity values: economic, social, philosophical, ethnic and or religious(Barilaro, Caterina., 2005). 
Gastronomy contains the knowledge of a civilization, from the scientific to the medical field, through art and religion: the spirit of an era is contained in food, important symbols are related to food, as well as metaphors of life. Our territories are real fields of food specialties and culinary traditions that must be rediscovered, known and capitalized on. Traditional food plays an important role in local identity, consumer behavior, the transfer of cultural heritage for future generations and the interaction of this heritage with the rest of the world. Today, traditional foods attract considerable attention as a country's potential resources for product identity (Mevhibe Albayrak* and Erdo an Gunes, 2010). And the loss of food traditions is an impoverishment of humanity and a warning that the only real challenge for man to die is to preserve his own cultural memory (Grimaldi, 2012).

The purpose of this paper is to capitalize on and promote the coliva as a traditional culinary product of the Republic of Moldova and as a tool for communicating the identity values of a people.

\section{il. Coliva - From Pagan Ritual to Christian Tradition}

Coliva for Romanians and Moldovans, kutia or kutea,socivo, kolivo for Russians and Ukrainians, Kó $\lambda \lambda \nu \beta \alpha$ - for Greeks, кољиво - for Serbs, kolivo for Bulgarians, this traditional food is considered reminiscent of the old agape or fraternal meals of early Christians, accepting at the same time, the fact that it is an extension of the old funerary feasts from the GrecoRoman cults (Lefter, Lucian-Valeriu, 2010). The word "coliva" comes from the ancient Greek word kolyvos, which was a grain of cereal (and in this sense passed into kolyvas). Kolyvos was also a very small coin (Speck Maria, 2007).

Even though it is part of the Orthodox Christian religious cult, it has its origins in antiquity, when the ancient Greeks offered boiled wheat with honey to the gods as an offering.

Thus, this secular custom began to be attributed a strong religious character, and wheat acquired a new meaning, which refers to the fact that after being cleaned and boiled it symbolizes the body of the one who leaves the world, after all life was fed with bread (wheat).

On the other hand, honey symbolizes eternal life, which is supposed to be sweet and soothing.

Coliva- as a culinary tradition of the Orthodox communities in the Balkans and Russia dates back to the early days of Christianity (Speck Maria, 2007). The miracle of Saint Theodore Tiron is the event that includes the coliva in the practice of the Church. This took place about 50 years after the saint's death, in the time of Emperor Julian the Apostate (361-363). For Orthodox Christians, the coliva is the material expression of faith in Jesus Christ and in the Resurrection. Christ the Savior was the first to use wheat as a metaphor for His Resurrection from the dead: The coliva is a food with a special symbolism and a strong spiritual charge. It symbolizes the Church, that is, all Christians, united by the same faith in God. Even during his sanctification, an extensive ritual process takes place. When the priest sings "Eternal Remembrance", the faithful hold the coliva with the priest and swing it from top to bottom. This means the connecting line between heaven and earth, the coliva being here the connecting element between the two worlds. Those who cannot directly reach the coliva plateau, touch with their hands those in front of them(Institutul Patrimoniului Cultural, 2019), (Lefter, Lucian-Valeriu, 2010), (Bobică, Radu., n.d.).

\section{in. Coliva to Orthodox Communities}

Whole grains have a special place in the Greek tradition. Boiled whole grain - coliva, sweetened and flavored, beautifies/crowns the table. In Greek, the coliva is mixed with almonds, raisins, nuts, pomegranate seeds and spices. Arrange on large silver trays and cover with a thick layer of powdered sugar. It was distributed in the 40 days after the funeral of the loved one, symbolizing the resurrection (Speck Maria, 2007), (Dalby, 2017).

In Russia and Ukraina the coliva is also called kutia or socivo (Table 1). The first mentions of kutia date back to the 12th century in the chronicle "Tale of Bygone Years" (Повестьвременныхлет). Initially it was cooked only from cereals and honey. Later in it was added poppy milk, raisins and chopped walnuts (Ribalco, A. (Рыбалко, А)., 2020). It is believed that the word "kutia" means "boiled cereals" or simply porridge.But, according to one version, this ritual dish could have its origin in the Ukrainian word "kut" - corner, because a pot of kutya, on holidays had to sit on a "pokutie" - in the honorable corner of the house, which was located diagonally to the oven. In this way the master of the house tried to improve the spirit of the hernia, of the frost.In the Breansk region of Russia, on the eve of Epiphany coliva (socivo) it was prepared from wheat grains with hemp and placed in the corner / red corner. Initially the kutia was prepared from wheat grains, later from barley, rice. Later, honey, chopped walnuts, poppy seed milk, dried fruit were added to it. Sometimes the coliva (kutia) was called "sochivo", due to the juice from the seeds (milk from poppy seeds, almonds or hemp, which was sweetened with honey) used as spices for these traditional dishes. There is also a variant of coliva, called black, which was cooked at memorial ceremonies and more often was called colivo and which differs from the other 2 in that it is less sweet, more reserved is the sensory profile. It is prepared more frequently from rice 
to which raisins are added (Corneva., V., lu. (Корнева B. Ю)., 2010).

It is considered that through the coliva our ancestors kept in touch with the deceased relatives. Therefore, in some peoples it was left on the table, with spoons for all family members. The purpose of this custom was for the spirits of the deceased to "taste" the coliva and share "information" with the living. For example, if someone's spoon was turned upside down, then it was considered that this person would leave the ranks of the living within a year.

For Bulgarians, the coliva, in addition to the classic ingredients, in some variants, also includes parsley (Table 1). It is remarkable that after being placed on plates or plates the coliva is decorated with the faces of the saints. The images of the saints are produced in a particularly impressive and remarkable way. With a fine brush, determine the outline of the icon on the coliva sprinkled with sugar. In some monasteries they use a matrix, which defines the boundaries of the icon (a system created in the post-Byzantine era). After marking the edges of the icon, the clothing and other pieces in the image are painted in different colors. Candied almonds are added(Chervenkov et al., 2013), ("How the monks of St. Forest make a coliva (Как монасите от Св. Гораправятколиво)," 2018) (Figure 1).

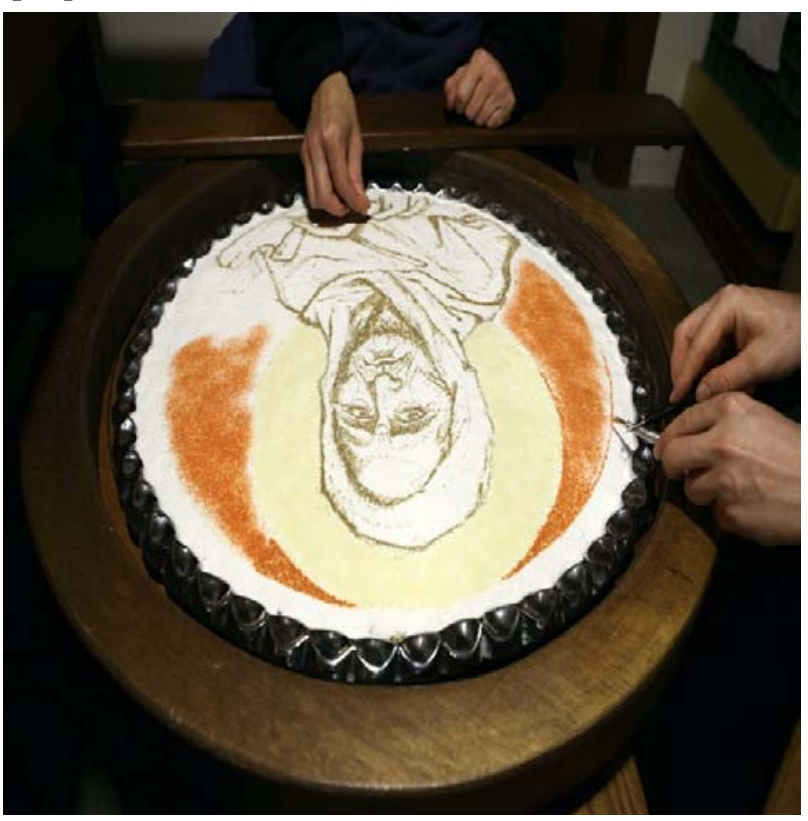

Figure 1: Painted coliva (in Bulgaria)

Source: Coliva: definiție și minunea Sfântului Teodor Tiron fotoreportaj de la decorareacolivei, n.d.

\section{a) Coliva in the Republic of Moldova}

Food has always been a significant identity landmark both at the individual level and at the group or national level. Many of the traditional dishes are perpetuated from one generation to another, such as: ritual bread, coliva, dumplings, cake, pies, wine, etc. (National cultural heritage as a resource for a sustainable development of the Republic of Moldova (Institute of Cultural Heritage, 2019), (R. Siminiuc and Țurcanu, 2020). The traditional food of the Republic of Moldova includes a very rich fund of knowledge, passed down from generation to generation, enriched with new gastronomic acquisitions as a result of cultural exchanges, adaptation to development, but also with new interpretations of old culinary practices. The traditional food system was formed in close connection with the main and secondary occupations, the natural environment and climatic conditions, religion and socio-historical conditions.

Coliva, among Romanians and Moldovans, has been used since Thracian times to celebrate ancestors, although it was also used as a profane food. The basic concept was related to the belief that the earth is a carrier of life and implicitly of seeds. As wheat was then the main seed, it was related to divinity. Currently, the coliva is an offering brought by the faithful to the church for sanctification, for Christmas, in honor of the holy day, on someone's name day or for the relief of the souls of the dead and their removal from eternal punishment. It was indispensable in the customs of burial and remembrance of the dead in the days of the Blessed Ones. It is the essential symbolic element, which is not missing from any commemorative event in honor of the dead.

In many parts of Bucovina there is a tradition to bring not only boiled wheat, i.e a coliva, to the church on the feast day of "SânToader", but also a glass of honey, above which is a stick of yellow beeswax, a jug of wine. or a loaf of bread (Roman, 1998). On the outskirts of Sibiu, on the day of the holy martyr "Haralambie", a coliva was prepared, which was given to the birds when they were touched by plagues or to scatter in the meadows, against insects and hail (Bobică, Radu., n.d.).

Although there are a lot of coliva recipes, and currently they are made from shelled, marketed wheat, ready to be cooked, however, the traditional artisanal recipe includes only whole grains of wheat, honey and later and crushed walnut kernels. 
Table 1: The peculiarities of the coliva in certain Orthodox communities

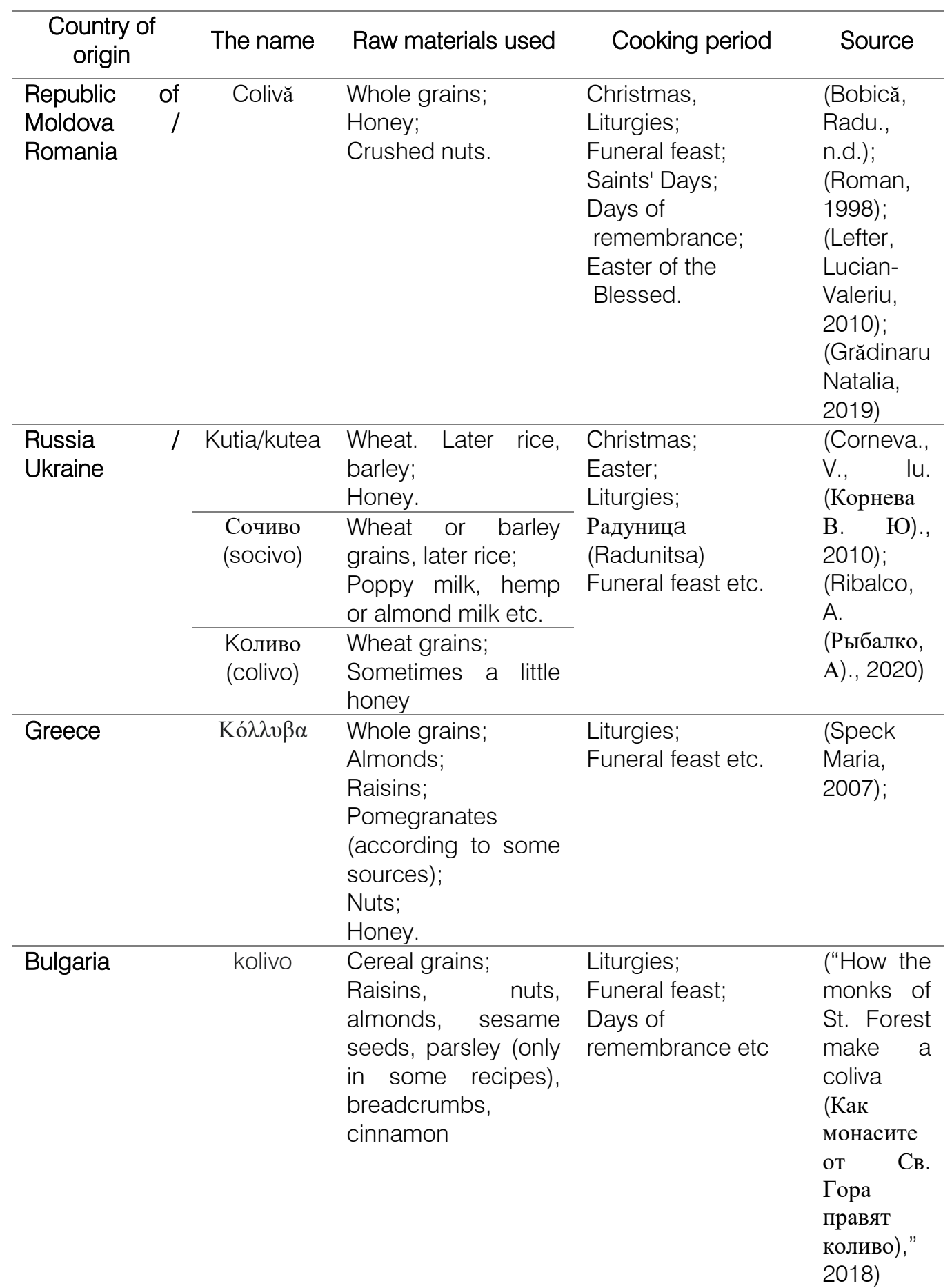

\section{Technological Retrospectives}

In the Republic of Moldova, but also in Romania, the preparation of the coliva was considered a very important event, followed by rituals observed with holiness. The housewife washed, dressed in clean clothes and prayed to God with pure thoughts and only after that did she start choosing wheat. Look for wheat with a large, clean grain, without the smell of ranced or mold.
Then, when the wheat was ready, it was washed in nine cold waters, symbolizing the nine angelic hosts. In some regions of the Republic of Moldova, cold water alternates with two more warm waters. According to tradition, this process symbolizes the nine angelic hosts. It "swelled" a little, then it was put in a huge wooden "piuă" and with a huge "chisoi" it was beaten delicately but for a long time to break a little (Figure 2).Older or younger children were often involved in this process: the younger ones to feel important, and the older ones to 
help, given the long time needed to grind the grains. The grains did not have to be crushed hard, just to be able to remove the higher states and slightly change the texture of the grain.
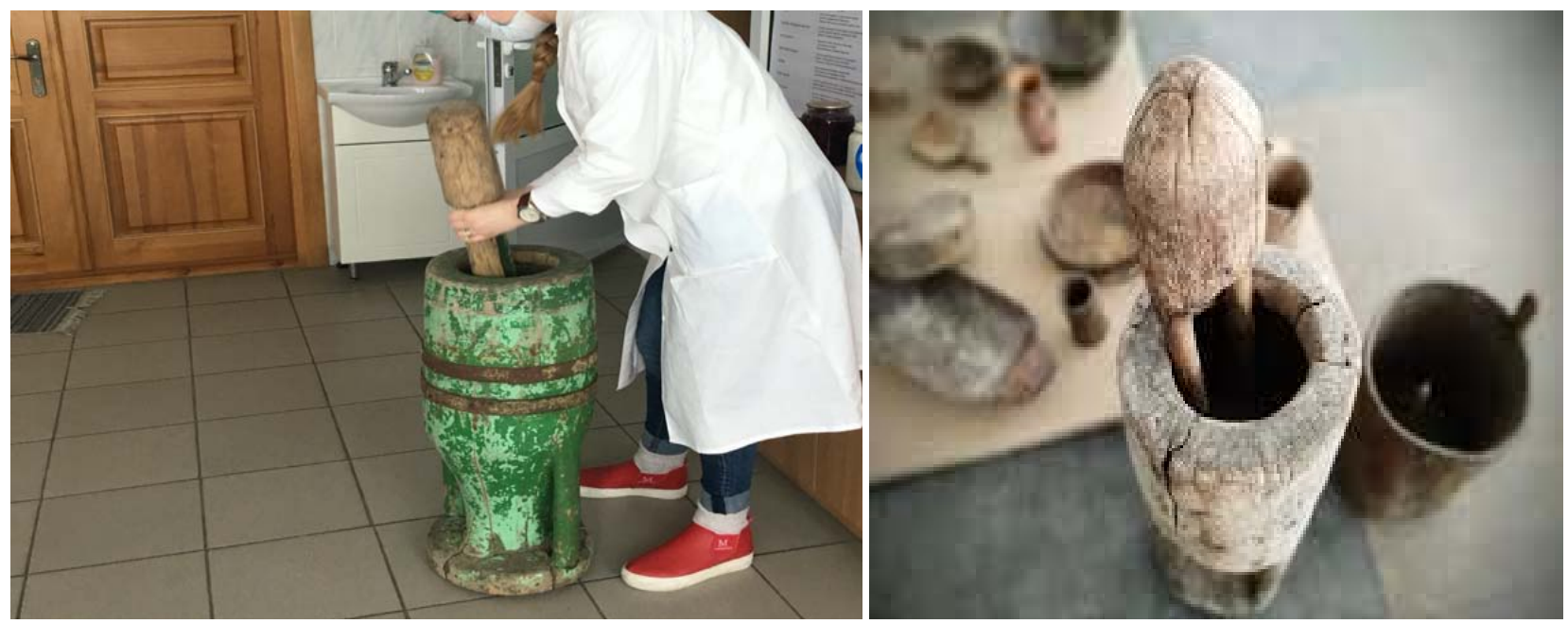

Figure 2: Examples of an old wooden „piuă” usedto "beat" grain

Used to reproduce the artisanal recipe of the coliva in cooking workshops with students. Culinary laboratory of the Food and Nutrition Department. Technical University of Moldova.

After light crushing, the wheat grains were removed from the bark and blown to escape the coating, as a result of partial husking. Then it was boiled in a pot with thick walls, over low heat, without chewing, so that the grains remained intact. The best option was to put it in the wood oven and leave it until the next day. The next day the housewives took the pot out of the oven (which was often still slightly warm), sweetened the wheat with honey and crushed walnuts. Mix well, patiently, then arrange on plates or plates, give a shape, most often cake.

They could be decorated with crushed walnuts. The artisanal technological process of preparing the coliva is represented in Figure 3. Currently the coliva is decorated with chocolate, dragees, cocoa cinnamon, etc (Figure 4). 


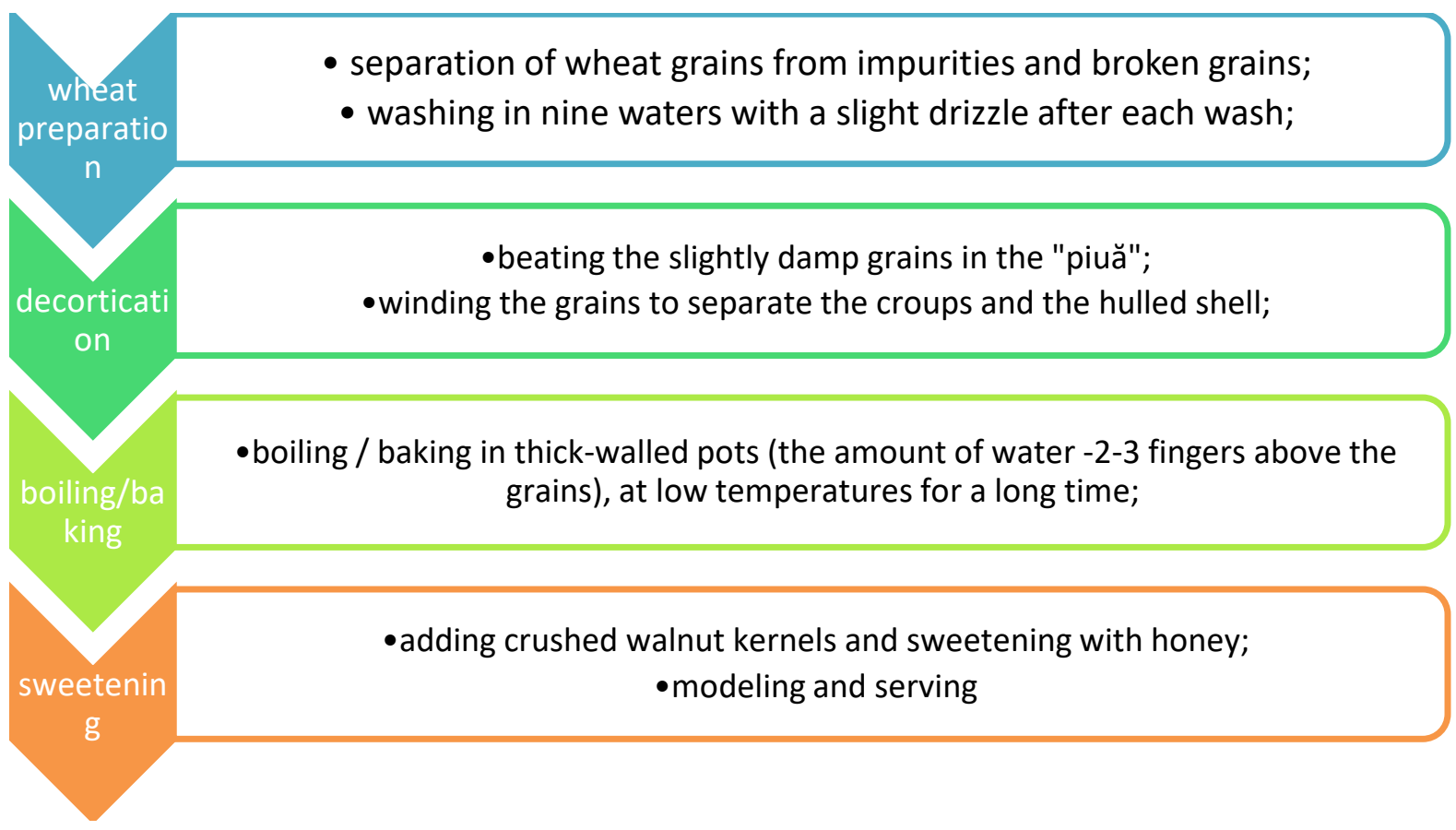

Figure 3: The artisanal technological process of cooking the coliva in the Republic of Moldova
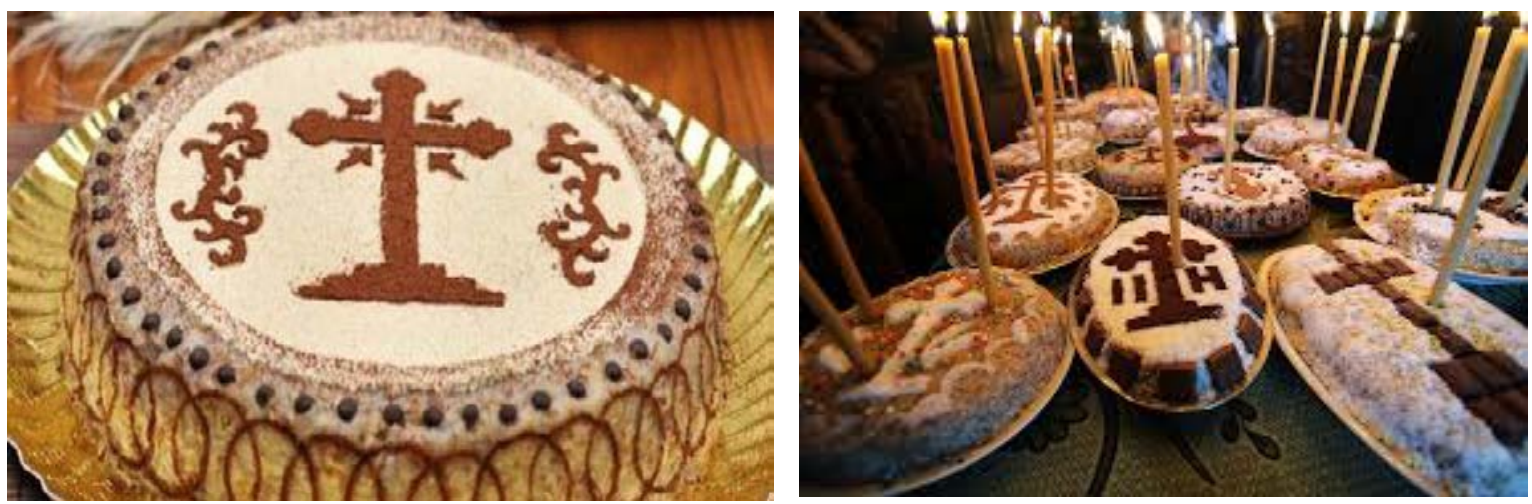

Figure 4: Colive for holiday(Coliva: definiție și minuneaSfântuluiTeodorTiron - fotoreportaj de la decorareacolivei, n.d.)

V. Changes in Hydration / Washing of GRAins

The process of preparing the coliva includes the stage of washing the wheat grains. Moisturizing the grains is a process that consists of soaking them in water with the subsequent increase in moisture content. Intuitively or knowingly, but it would seem that this procedure, with a religious connotation in the case of the coliva, would also have a scientific justification: our ancestors, in this way, formed a temperature gradient, which in one way or another, when the grains were wilted, they led to the formation of cracks and the outer layers of the coating and, respectively, to an easier removal of it (Miano and Augusto, 2018), (Rodica Siminiuc and Țurcanu, 2020).

During washing, due to the diffusion process and, depending on the permeability of the seed layer (bran), partial hydration of the grains takes place, which helps to reduce the cooking time. The hydration process promotes the activation of cell wall enzymes, decreases the degree of polymerization of rhamnogalacturonan I and increases the solubility of polygalacturonan and galactan, which results in better solubility of polysaccharides and a shorter cooking time(MartínezManrique et al., 2011).

In addition, hydration improves homogeneous gelatinization of starch and homogeneous denaturation of proteins during cooking(Wood, 2017). Moreover, heat transfer through grains during cooking is enhanced by absorbed water, thus improving the inactivation of antinutritional factors such as protease inhibitors, lectins, saponins, phytates, alkaloids and indigestible oligosaccharides(Wang et al., 2009), (Coulibaly et al., 2010). The culinary technology of cooking the coliva for a long time at low temperatures (usually the coliva was put in the wood oven after baking bread and other goodies that the housewife prepared) ensures a uniform and 
slow distribution of heat. The advantages were many: the moderate temperature guaranteed a perfect texture of the wheat grains, the richness of the aromas and the preservation of the nutrients.

\section{Vi. Conclusions}

Traditional foods over time, have managed to create a strong and mutual complicity, a history, a culture, a tradition that has given them strong individualizing characteristics and that have marked the identity of each human group. Today, traditional foods attract considerable attention as a country's potential resources for product identity. The loss of food traditions is an impoverishment of humanity and a warning that the only real challenge for man to death is to preserve his own cultural memory.

Coliva, managed to intertwine so delicately and beautifully in the identity of the Moldovan people, that now its deficiency in traditional culture is inconceivable. Undoubtedly, it plays an individual identity role, but also an important ethnic and spiritual one. It is the expression of culture, the object and subject of cultural and religious change. He is a promoter of Slow Food, a formidable driver of well-being and health. It is a condensate of social, environmental, historical, religious values.

Over time, the coliva has symbolically served several areas and meanings of culture, magically providing for the spiritual and material needs of the Moldovan people.

\section{References Références Referencias}

1. Barilaro, Caterina., 2005. L'alimentazione tra cultura e identità. Presented at the Attidell 'Ottavo Seminario Internazionale di Geografia Medica, Edizioni Rux, Perugia, pp. 161-167.

2. Bobică, Radu., n.d. Dictionar de termeni și concept teologice. www.coresi.net.

3. Chervenkov, N.N., Duminika, I., Kalchev, K. (Eds.), 2013. Bŭlgariîa: metropoliî́a diaspora: sbornik po sluchaĭ 65-godishninata na d.i.n. Nikolă Chervenkov. S.Ș.B, Kishinev.

4. Coliva: definiție și minunea Sfântului Teodor Tiron fotoreportaj de la decorarea colivei, n.d. (Corneva., V., Iu. (Корнева В. Ю)., 2010. The symbolism of kutia in the ritual culture of Russians (Символика кутьи в ритуальной культуре русских). Tomsk State University Bulletin (Вестник Томского государственного университета) 338, 72-75.

5. Coulibaly, A., Kouakou, B., Chen, J., 2010. Phytic Acid in Cereal Grains: Structure, Healthy or Harmful Ways to Reduce Phytic Acid in Cereal Grains and Their Effects on Nutritional Quality. American J. of Plant Nutrition and Fertilization Technology 1, 1-22. https://doi.org/10.3923/ajpnft.2011.1.22
6. Dalby, R., 2017. Gifts of the gods - a history of food in greece. Fieldhouse, P., 1998. Food and nutrition: customs and culture, 2. ed., reprinted. ed. Thornes, Cheltenham.

7. Grădinaru Natalia, 2019. The material popular culture of Romanians / Moldovans (Cultura popular materială a românilor/moldovenilor). Pro Patrimoniu Cultural.

8. Grimaldi, P., 2012. Cibo e rito: il gesto e la parola nell'alimentazione tradizionale, Tutto e subito. Sellerio, Palermo. How the monks of St. Forest make a coliva (Как монасите от Св. Гора правят коливо), 2018. Добротолюбие. Institutul Patrimoniului Cultural, 2019. National Cultural Heritage as a resource for sustainable development of the Republic of Moldova (Patrimoniul Cultural Naţional ca resursă pentru o dezvoltare durabilă a Republicii Moldova), 1st ed. NotografPrim, Chisinau.

9. Lefter, Lucian-Valeriu, 2010. Revista de Etnografie, Științele Naturii și Muzeologice. Buletin științific. Muzeul Național de Etnografie și Istorie Naturală 13, 100-118.

10. Martínez-Manrique, E., Jacinto-Hernández, C., Garza-García, R., Campos, A., Moreno, E., BernalLugo, I., 2011. Enzymatic changes in pectic polysaccharides related to the beneficial effect of soaking on bean cooking time: Enzymatic changes in soaked bean pectin. J. Sci. Food Agric. 91, 23942398. https://doi.org/10.1002/jsfa.4474

11. Mevhibe Albayrak*, Erdo an Gunes, 2010. Traditional foods: Interaction between local and global foods in Turkey. African Journal of Business Management 4.

12. Miano, A.C., Augusto, P.E.D., 2018. The Hydration of Grains: A Critical Review from Description of Phenomena to Process Improvements: Hydration of grains: a review.... Comprehensive Reviews in Food Science and Food Safety 17, 352-370. https://doi.org/10.1111/1541-4337.12328

13. Ribalco, А. (Рыбалко, А)., 2020. Kutia, socivo and kolivo. What is the peculiarity of these ritual dishes (Кутья, сочиво и коливо. В чем особенность этих ритуальных блюд). Argumenti I Facti (Аргументы и фракты).

14. Roman, R.A., 1998. Bucate, vinuri și obiceiuri românești. Paideia, București.

15. Siminiuc, R., Țurcanu, D., 2020. IMPACT OF ARTISANAL TECHNOLOGIES ON THE QUALITY INDICES OF THE COZONAC. Food systems 3, 2531. https://doi.org/10.21323/2618-9771-2020-3-325-31

16. Siminiuc, Rodica, Țurcanu, D., 2020. The Impact of Hydrothermal Treatments on Technological Properties of Whole Grains and Soriz (\&lt; \& \& gt;Sorghum oryzoidum \&lt;/i\&gt;) Groats. FNS 11, 955-968. https://doi.org/10.4236/fns.2020.1110067 
17. Speck Maria, 2007. A Gift of Grains. Gastronomica 7, 84-87. https://doi.org/10.1525/gfc.2007.7.4.84

18. Wang, N., Hatcher, D.W., Toews, R., Gawalko, E.J., 2009. Influence of cooking and dehulling on nutritional composition of several varieties of lentils (Lens culinaris). LWT - Food Science and Technology 42, 842-848. https://doi.org/10.10 16/j.Iwt.2008.10.007

19. Wood, J.A., 2017. Evaluation of Cooking Time in Pulses: A Review. Cereal Chemistry Journal 94, 3248. https://doi.org/10.1094/CCHEM-05-16-0127-FI 